\title{
Article
}

\section{Service user involvement in practitioner education: movement politics and transformative change}

McKeown, Mick, Dix, Julie, Jones, Fiona, Carter, Bernie, Malihi-Shoja, Lisa, Mallen, Ernie and Harrison, Nigel

Available at http://clok.uclan.ac.uk/11941/

McKeown, Mick ORCID: 0000-0003-0235-1923, Dix, Julie, Jones, Fiona, Carter, Bernie ORCID: 0000-0001-5226-9878, Malihi-Shoja, Lisa, Mallen, Ernie and Harrison, Nigel (2014) Service user involvement in practitioner education: movement politics and transformative change. Nurse Education Today, 34 (8). $1175-1178$.

It is advisable to refer to the publisher's version if you intend to cite from the work. http://dx.doi.org/10.1016/j.nedt.2014.03.016

For more information about UCLan's research in this area go to http://www.uclan.ac.uk/researchgroups/ and search for <name of research Group>.

For information about Research generally at UCLan please go to http://www.uclan.ac.uk/research/

All outputs in CLoK are protected by Intellectual Property Rights law, including Copyright law. Copyright, IPR and Moral Rights for the works on this site are retained by the individual authors and/or other copyright owners. Terms and conditions for use of this material are defined in the policies page.

\section{CLoK}

Central Lancashire online Knowledge www.clok.uclan.ac.uk

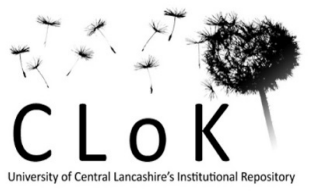




\section{Service user involvement in practitioner education: movement politics and transformative change}

\section{Abstract}

This paper will attempt to both celebrate key developments and best practice involving the users of health and social care services in programmes of practitioner education in a UK context, and offer a critical appraisal of the extent to which such initiatives meet some of the more transformative objectives sought by service users activists for change. The approach is largely that of a discussion paper but we illustrate some of the themes relating to movement activism with selected data. These data -relate to earlier research and two specially convened focus groups within the Comensus initiative at the University of Central Lancashire; itself constituted as piece of participatory action research. We conclude that universities represent paradoxical sites for the facilitation of debate and learning relevant to key issues of social justice and change. As such, they are places that can impede or support movement aims. Particular strategic responses might be more likely to engender progressive outcomes. These ought to include the presence of critically engaged academic staff operating within a scholarly culture that fosters forms of deliberative democratic decision making.

Key words: health and social care education, politics, service user involvement, social movements

\section{Introduction}

Pedagogical practices supporting service users' contributions have grown significantly in recent times (McKeown et al. 2010, Terry 2012). These are matched by a proliferation of policy rhetoric urging increasing levels of involvement in almost all aspects of the organisation and delivery of services (Barnes \& Cotterell 2012, McKeown \& Jones 2014). Such developments are international and extend across different disciplines (Towle et al. 2010) with a significant nursing focus in the UK. The idea of service user involvement is now essential to the lexicon of educators, policy makers and practitioners. This has undoubtedly become part of conventional thinking, urging promotion of autonomy, cooperation, recovery objectives and a humanising of care. The latter point demands particular attention in the face of a prevailing moral panic (Cohen 1972) over perceived deficits in compassion and nurse education (see Odone 2012). 
Progressive developments have, therefore, been underpinned by the infiltration of ideologies of empowerment, citizenship and consumerism into policy prescriptions for wider governance and participation in the public sphere. Questions remain, however, regarding inherent contradictions or the extent to which the rhetoric is matched by actual practice-level or societal change. Proselytisers and naysayers for different types of involvement can be found amongst the diverse ranks of pedagogues, practitioners, service managers, service users and social movement activists. In this paper, service user and carer involvement in practitioner education will be located in an historical overview of UK government policy before turning to review the impact for practitioner education programmes. There then will be a discussion of the relevance of understanding such involvement through the lens of movement politics, drawing upon focus group data provided by participants in the Comensus initiative at the University of Central Lancashire. One intention is to move debate and discussion around the value of service user involvement away from anodyne and simplistic consumerist notions of voice, choice and public engagement onto a more dynamic politicised territory. That is not to say that progress cannot be made upon this territory, nor that consumerism has monopoly interest in matters of 'voice, choice and engagement'. Rather, an uncritical stance towards the same can result in superficial, tokenistic or 'tick-box' forms of involvement instead of empowered change. All of this requires a critical look at the role of universities in nurturing or impeding the forms of social space which might better support the realisation of service users' demands for social justice and change across health care services and wider society.

\section{Public participation and involvement policies}

UK government policy has discursively championed various approaches to citizen voice within health care with increasing emphasis in recent times. That said, there is a dynamic history of interest in public participation stretching back many decades. Relevant legislation and policy sits within broader systems of governance that support consumer rights and democratic participation across the public domain. Involvement policies for health care organisations, in particular, resonate with empowerment ideals, seeking equality in the social relations between practitioners and service users. Latterly this is framed in the language of co-production. Gorsky (2007) describes a 200 year heritage for public participation dating to the implicit democracy of early mutual friendly societies and arriving at present day consumerist policies of service user engagement and involvement. 
The turn to consumerism is of interest in that it coincides with the ascendancy of a global neo-liberal polity that threatens the survival of state welfare and health services. Interestingly, the same forces have ushered in increasing corporatisation of universities as part of the more general retreat from publically provided services (Rolfe 2013). The rise of neo-liberal governance and associated privatisations and marketisation of health care provision has been in conjunction with assaults on welfare support for the most disadvantaged in society (Ramesh 2012). Many such persons might identify as disabled or users of health and social care services (McKeown et al. 2013). Critics suggest that policies promoting public engagement and involvement are much too bound up with a wider mission of governance and social control (Cooke \& Kothari 2002).

It is within this broad political-economy that democratic deficits arise. Governments face crises of legitimacy, and new social movements appear, framed in issue based or identity politics; for example, various feminisms, gay activism and civil rights groups (Habermas 1976, 1981). Hence, social movements have been constituted with regard to disability or service user identities. These make moral and political demands for, amongst other things, appropriate rights, better health services, and more inclusive, less-stigmatising communities (Rogers \& Pilgrim, 1991; Brown \& Zavetoski, 2005; Williamson, 2008). Arguably, service users who participate in involvement practices within universities bring with them, either partially or wholesale depending on prior affiliations, a number of the characteristics of movement activism (McKeown et al. 2010).

Interestingly, the more radical cohorts of any service user movement would find themselves critical of simple consumerism, but opportunistically taking advantage of policy initiatives to more assertively take up a place in the public sphere (Deber et al. 2005, Clarke 2007, Cowden \& Singh 2007). The working out of such developments in the higher education sector is arguably in tension with more progressive developments in public engagement.

\section{Service user involvement in university settings}

Nursing and other practitioner education has willingly taken up the challenge of bringing service user and carer involvement into universities. This mission has also extended into associated research and community engagement practices (see McKeown et al. 2010). Regulatory bodies such as the NMC (2010) have stipulated common standards for pre-registration nurse education that refer explicitly to 
the desirability of involving service users and carers in programme design, delivery and assessment. An extensive literature provides detailed description, commentary and inquiry into such involvement covering student selection, face to face teaching, curriculum planning, course validation and evaluation (see Wykurz \& Kelly 2002, Felton \& Stickley 2004, Bassett et al. 2006, Beresford et al. 2006, Lathlean et al. 2006, Repper \& Breeze 2007, Brown \& Young 2008, Morgan \& Jones 2009, Towle et al. 2010, McKeown et al 2010, Dix et al. 2014). In tandem with this focus on teaching and learning has been a concomitant increase in involvement in research practices (see Church 2005, Hanley 2005, Involve 2007, Frankham 2009). A consequence of these developments has been that various quality assurance and grant approval systems are now geared up to take account of levels of involvement and participation. Inquiry into the motivation of service users to get involved in education programmes reveals that a desire to 'make a difference' to health and social care services is prominent along with interests in widening access to higher education (McKeown et al. 2012). Despite this growth in participation, neither an actual impact upon services has been confidently demonstrated nor are relevant study designs easy to conceive, implement or resource (Repper \& Breeze 2007, Rhodes 2012).

Government policy and professional interest in service user involvement is open to wide-ranging critique. Various commentators have posed criticism of the key concepts and language associated with involvement, which is clearly understood differently by different people, groups or institutions (Beresford 2005). Arguably there is a lack of attention within policy prescriptions to detailing ideas for how best to implement involvement (Duffy 2008) and thoroughly address service user demands for the organisation of services (Connor \& Wilson 2006). The terminology can be challenged for being implicitly disempowering, insufficiently acknowledging other diversity issues, or define people uncritically in terms of pathology (Lewis 2005). Furthermore, involvement practices can fetishise unrealistic or un-called for ideals of representativeness (Beresford 1994) or inadequately face up to issues of tokenism (Carter 2009, Horrocks et al. 2010). These shortcomings fail to consistently value service user views as valid commentary on services; with some voices being too easily discounted or ignored. Similarly, profound questions can be posed over the extent to which models of service user involvement in any context can escape powerful constraining forces such as tendencies to incorporation and co-option (see Beresford 2002, Lewis 2005, Pilgrim 2005, Carr 2007). Conversely, efforts have been taken to exemplify progressive values of participation, cooperation and authenticity within involvement practices. Such concerns have been influential in the construction of 
various evaluative tools which account for levels of partnership (Arnstein 1969, Tew et al. 2004, Tritter \& McCallum 2006).

\section{Activist identities and the academy}

Given the politicised and contested territory on which service user involvement must take place, it has been pointed out that service users can be viewed as social movement activists (Brown \& Zavetoski 2005). In effect, they take their place along-side a diversity of groupings including, for example, disability rights movements, patient and carer groups, psychiatric survivor collectives, who all, variously, assert progressive political claims for a better world (see Crossley 2006, Spandler 2006, Beresford \& Branfield 2012). Hence, when 'user involvement' programmes are organised in university settings, the social space of the academy becomes to some extent colonised by service user activism.

Such experiences were confirmed in research carried out as part of the establishment of our Comensus initiative (McKeown et al. 2010, 2012) and two focus groups specially convened for the purpose of inquiring into matters of motivation and identity ( $n=12$ service users). Comensus coordinates and organises service user and carer involvement in various aspects of the work of the University of Central Lancashire. The majority activity supports teaching and learning relating to health and social care. Other inputs include involvement in community engagement, research and strategic developments, such as those concerning disability access. Comensus has developed its own democratic structures, including the Community Involvement Team, a group of around 20 individuals who are the autonomous decision making centre of the initiative. The wider network comprises hundreds of service users and carers and scores of affiliated community groups.

Comensus was initially organised as a participatory action research project, with ethical approval for all data collection granted via the university's ethics committee. Latterly, two focus groups were organised to specifically enquire into questions regarding why people elect to participate in Comensus, what sustains their involvement and how involvement impacts upon sense of self; how people see themselves or how they think they are viewed by others. There was no strict selection criteria beyond participants being service users or carers currently engaged in involvement practices at the university. Our analysis suggests that service user and carer participants do make use of 
'activist' concepts in making sense of their social relations. To illustrate these points a brief selection of quoted service user voices follow.

In a variety of different ways, personal motivation was framed in terms of seeking social change over and above any sense of personal or material reward (Delanty 2003, McKeown et al 2012):

Look at all these people. Do you think they are here for themselves or to make something out of it? No, they want to make a difference .... They want to make good things happen and stop the bad things in services. That's what I feel.

This 'activism' is reported as leading to fulfilling states of self-realisation and meaning-making (Melucci, 1996) via "a goal, a reason, a meaning in life", for example, through a sense of being personally valued:

I enjoy this stuff, it makes me feel valued in ways I never thought of before ... in ways if I'm honest about it I wasn't allowed to before.

Other times, this sense of worth is gained through observing the difference in 'real time' in the classroom:

When from time to time you see students make that leap, you see what you have said has moved them, it makes it all worthwhile ... that feels great for me.

Social movement-type practices are reported in terms of affinities for organisational forms and relations that: reflect flattened hierarchies (and resentment of established university hierarchy and status differentials), common goals, deliberative democratic discussions and decision-making, shared activities (everybody does a bit of everything), and, very importantly, a valuing of comradeship and sociability as a mainstay of sustaining commitment (Rothschild-Whitt 1979). Within 
Comensus there was a sense of "friendship ... we all get along. In other groups it's all work ... we get things done in an easier way". This notion of friendship linked to the sense of "solidarity and familiarity" that had developed as people "settled into the environment" and were able to reflect:

We get together as a group, we get to know each other, we have a similar cause, we share experience.

This feeling of being together and sharing a cause was evident in wanting to make changes:

on disability issues you've got to start local. So many things need changing ... We've all got things in common.

The activist flavour of Comensus is reflected to some extent in participants seeking influence in the university on a wider range of issues than was ever part of the initial invitation to get involved for example, infiltrating strategic decision making forums on matters such as disability access at all levels of the organisation. Furthermore, the contribution to pedagogy has not stopped with the crucial linking of personal narrative to curriculum defined learning objectives. Rather, the participating service users have gone on to write and lead their own modules focused entirely on the practice of involvement and incorporating activist theory and praxis. In another example, colleagues from Ryerson University in Toronto have explicitly facilitated a confederacy of academic and service user activists relating to critical understandings of mental health. This has been styled as 'mad activism in the academy', wherein one can adopt 'mad identified' or 'mad positive' identities (Church 2013, Reville 2013).

It is not only the service users who might view themselves as activists for change. Arguably, academics are also eligible for this identity and may seek it out. For Calhoun (2008) activist scholarship is as old as Aristotle, and public intellectuals and critically engaged academics (Cresswell \& Spandler 2013) are an important part of the university landscape. The extent to which universities can become radical places might depend upon bringing together critically minded staff and community activists. The service user involvement territory could have quite particular potential in 
this regard (McKeown \& Jones 2012). In this context there is an opportunity to take time over strategic discussions, perhaps best understood in terms of Habermas's $(1986,1987)$ description of deliberative democracy. Ideally this is replete with respectful acknowledgement of difference, equalised power differentials, and reasoned and reasonable persuasion amongst comrades open to a change of mind. Such interaction does not necessarily result in easy agreement, and the starting point may be typified by quite contested standpoints or develop into unsettled or unsettling conversations (Church 1996). Helen Spandler (2009) has written persuasively about the sorts of creativity that can emerge when easy consensus might be more difficult to achieve. For instance in paradoxical social spaces, where difference and varied points of view may be important characteristics of prevailing social relations.

These idealised ways of thinking about democratising social space, activist communication and social change are reflected in key reflections on cooperation and pro-sociality linked to setting (Fetchenhauer et al. 2006, Sennett 2012). If supportive conditions can be maximised (and there are grounds for believing universities might be well placed to achieve this), then the very act of communication is an essential part of making social change. Interestingly, forms of participatory action research also exemplify democratised communication as a vehicle for change and an appreciative inquiry project of ours is currently focused upon the triad of staff, student and service user relations to effect positive developments in involvement practices within the university (Dix et al. 2014).

\section{Conclusions}

Arguably, service user participants in university involvement initiatives are interested in more than just simple involvement and voice. At least in part, or when certain conditions are optimised, activism for progressive change can come to the fore. Critically engaged academics are well-placed to support such praxis. This coincidence of activist interest has probably never been so important. Given prevailing concern with compassion deficit and organisational failings across health and social care services on the one hand, and instability in the university sector induced by cost-cutting and reorganisation on the other, strategic alliances are paramount. Effective coalitions between new and old social movements, including broadly constituted service user groups and public sector trade unions (McKeown et al. 2014) represent one set of, as yet unrealised, possibilities for resistance. Regardless, organised service user interests will continue to make radical demands upon services 
and the academy alike. Practitioners and academics need to ask themselves: are we ready? Are we with you? The answers to these questions may ultimately determine the extent to which demands and action for transformative change across services or wider society are indeed successful. 


\section{References}

Arnstein, S. (1969) A Ladder of Citizen Participation. Journal of the American Institute of Planners, 35, 216-224.

Barnes, M. \& Cotterell, P. (2012) Introduction: from margin to mainstream. In M. Barnes \& P. Cotterell (eds) Critical perspectives on user involvement. Policy Press, Bristol. pp. xv-xxvi.

Basset, T., Campbell, P. \& Anderson, J. (2006) Service user/Survivor Involvement in Mental Health Training and Education: Overcoming the Barriers. Social Work Education, 25, 393-402.

Beresford P. (2005) 'Service user': regressive or liberatory terminology? Disability \& Society, 20, 469477.

Beresford, P. \& Branfield, F. (2012) Building solidarity, ensuring diversity: lessons from service users' and disabled people's movements. In M. Barnes \& P. Cotterell (eds) Introduction: from margin to mainstream. In M. Barnes \& P. Cotterell (eds) Critical perspectives on user involvement. Policy Press, Bristol. pp 217-233.

Beresford, P., Branfield, F., Taylor, J., Brennan, M., Sartori, A., Lalani, M., \& Wise, G. (2006) 'Working Together for Better Social Work Education'. Social Work Education, 25, 326-331.

Brown, K. \& Young, N. (2008) Building capacity for service user and carer involvement in social work education. Social Work Education. The International Journal, 27 (1), 84-96.

Brown, P. \& Zavetoski, S. (2005) Social movements in health: an introduction. In P. Brown \& S. Zavetoski (Eds) Social Movements in Health. Blackwell Publishing, Oxford. pp. 1-16. 
Carr, S. (2007) Participation, power, conflict and change: Theorizing dynamics of service user participation in the social care system of England and Wales. Critical Social Policy, 27, 266-276.

Carter, B. (2009) Tick box for child? The ethical positioning of children as vulnerable, researchers as barbarians and reviewers as overly cautious. International Journal of Nursing Studies. 46 (6), 858864.

Church, K. (1996). Forbidden Narratives: Critical Autobiography as Social Science. Routledge, London.

Church, K. (2005) Conflicting knowledge/s: User involvement in the field of knowledge. In Tilley, S. (ed.) Field of Knowledge of Psychiatric and Mental Health Nursing. Blackwell, London. pp. 181-185.

Church, K. (2013) Making madness matter in academic practice. In B. Le Francois, R. Menzies \& G. Reaume (eds) Mad matters: a critical reader in Canadian mad studies. Canadian Scholars Press, Toronto. pp. 181-190.

Clarke, J. (2007) Citizen-consumers and public service reform: At the limits of neo-liberalism? Policy Futures in Education, 5, 239-248.

Cohen (1972) Folk devils and moral panics. MacGibbon \& Kee, London.

Connor, S. \& Wilson, R. (2006) It's important that they learn from us for mental health to progress. Journal of Mental Health, 15, 461-474.

Cooke, B. \& Kothari, U. (2002) Participation: The New Tyranny? Zed Books, London.

Cowden, S. \& Singh, G. (2007) The 'User': Friend, foe or fetish?: A critical exploration of user involvement in health and social care. Critical Social Policy, 27 (1), 5-23. 
Cresswell, M. \& Spandler, H. (2013) The engaged academic: academic intellectuals and the psychiatric survivor movement. Social Movement Studies, 12 (2), 138-154.

Crossley, N. (2006) Contesting psychiatry: social movements. In Mental Health. Routledge, London.

Deber, R. Kraetschmer, N. Urowitz, S. Sharpe, N. (2005) Patient, consumer, client, or customer: what do people want to be called? Health Expectations, 8, 345-351.

Delanty, G. (2003) Community. Routledge, London.

Dix, J., Carter, B., Gibbon, C., McKeown, M. Harrison, N. (2014) Developing an Understanding of the Contribution of Service Users to Nurse Education in the Classroom: A HEA funded doctoral programme. Health and Social Care Education,

Duffy, J. (2008) Looking out from the middle: user involvement in health and social care in Northern Ireland. SCIE, London.

Felton, A. \& Stickley, T. (2004) Pedagogy, Power and Service User Involvement. Journal of Psychiatric and Mental Health Nursing, 11, 89-98.

Frankham, J. (2009) Partnership research: a review of approaches and challenges in conducting research in partnership with service users. ESRC National Centre for Research Methods Review Paper. NCRM/013. ESRC, London. 
Gorsky, M. (2007) Memorandum submitted to the Health Select Committee inquiry into Public and Patient Involvement in the NHS January 2007. History and Policy, London School of Hygiene and Tropical Medicine/Centre for History in public Health, London.

Habermas, J. (1976) Legitimation crisis. Heinemann, London.

Habermas, J. (1981) New social movements. Telos, 49, 33-7.

Habermas, J. (1986) The theory of communicative action. Volume 1. Reason and the rationalization of society. Polity Press, Cambridge.

Habermas, J. (1987) The theory of communicative action. Volume 2. The critique of functionalist reason. Tr. T. McCarthy. Polity Press, Cambridge.

Calhoun, C. (2006) Foreword. In C. Hale (ed) Engaging Contradictions: Theory, Politics, and Methods of Activist Scholarship. University of California Press, Berkeley, CA. pp. xiii-xxvi.

Hanley, B. (2005) Research as empowerment? User involvement in research: building on experience and developing standards. Toronto Seminar Group/Joseph Rowntree Foundation, York.

Involve (2007) Good practice in active public involvement in research. Involve, Eastleigh.

Lathlean, J., Burgess, A., Coldham, T., Gibson, C., Herbert, L., Levett-Jones, T., Simons, L. \& Tee, S. (2006) Experiences of service user and carer participation in health care. Nurse Education Today, 26, 732-737.

Lewis, L. (2005) User involvement within Scottish mental health policy: locating power and inequality. Scottish Affairs, 51, 79-107. 
Melucci, A. (1996) Challenging Codes: Collective Action in the Information Age. Cambridge University Press, Cambridge.

McKeown, M., Cresswell, M. \& Spandler, H. (2014) Deeply engaged relationships? Trade Unionism and the Organized Left's Alliance Building with Psychiatric Survivors in the UK. In B. Burstow, S. L. Diamond and B. A. LeFrancois (eds) Psychiatry disrupted: theorizing resistance and crafting the (r)evolution. McGill/Queen's University Press, CA.

McKeown, M. \& Jones, F. (2014) Service user involvement: a critical view of policies, practice and politics. In I. Hulatt (ed) Mental health policy for nurses. Sage, London.

McKeown, M. \& Jones, F. (2012) Can universities be radical places? Asylum, 19 (1), 20-22.

McKeown, M., Jones, F. \& Spandler, H. (2013) Challenging austerity policies: democratic alliances between survivor groups and trade unions. Mental Health Nursing,

McKeown, M., Malihi-Shoja, L. \& Downe, S. supporting The Comensus Writing Collective (2010) Service user and carer involvement in education for health and social care. Wiley-Blackwell, Oxford.

McKeown, M., Malihi-shoja, L., Hogarth, R., Jones, F., Holt, K., Sullivan, P., Lunt, J., Vella, J., Hough, G., Rawcliffe, L., Mather, M. \& The CIT. (2012) The value of involvement from the participants' perspective: not just a cash nexus. Nurse Education Today: special issue on service user \& carer involvement, 32, 178-184.

Morgan, A. \& Jones, D. (2009) Perceptions of service user and carer involvement in healthcare education and impact on students' knowledge and practice: a literature review. Med Teach. 31 (2), $82-95$ 
Nursing and Midwifery Council. (2010) Standards for pre-registration nursing education. NMC, London.

Odone, C. (2012) Nurses need compassion - not a degree. The Telegraph.

http://blogs.telegraph.co.uk/news/cristinaodone/100192610/nurses-need-compassion-not-adegree/ accessed February $2^{\text {nd }} 2014$.

Pilgrim, D. (2005) Protest and co-option: the recent fate of the psychiatric patient's voice. in A. Bell \& P. Lindley (eds) Beyond the Water Towers: The unfinished revolution in mental health services 19852005. Sainsbury Centre for Mental Health, London. pp. 17-26.

Ramesh, R. (2012) Conservative assault on welfare shows party's nasty, authoritarian streak. The Guardian, Tuesday, October 9, 7.

Repper, J., \& Breeze, J. (2007). User and carer involvement in the training and education of health professionals: A review of the literature. International Journal of Nursing Studies, 44, 511-519.

Reville, D. (2013) Is mad studies emerging as a new field of inquiry? In B. Le Francois, R. Menzies \& G. Reaume (eds) Mad matters: a critical reader in Canadian mad studies. Canadian Scholars Press, Toronto. pp. 170-180.

Rhodes, C. A. (2012). User involvement in health and social care education: A concept analysis. Nurse Education Today, 32, 185-189.

Rogers, A. \& Pilgrim, D. (1991) "Pulling down churches": accounting for the British mental health users movement. Sociology of Health and IIIness, 13 (2), 129-148.

Rolfe, G. (2013) The university in dissent: scholarship in the corporate university. Routledge, London. 
Sennett, R. (2012) Together: the rituals, pleasures and politics of cooperation. Allen Lane, London.

Spandler H (2006). Asylum to action: Paddington day hospital, therapeutic communities and beyond. Jessica Kingsley Publications, London.

Spandler, H. (2009) Spaces of psychiatric contention: a case study of a therapeutic community. Health \& Place, 15, 672-678. Health \& Place, 15, 672-678.

Terry, J. (2012). Service user involvement in pre-registration mental health nurse education classroom settings: A review of the literature. Journal of Psychiatric \& Mental Health Nursing, 19 (9), 816-829.

Tew, J., Gell, C. \& Foster, F. (2004) A Good Practice Guide. Learning from Experience. Involving Service users and Carers in Mental Health Education and Training. Mental Health in Higher Education/NIMHE, Nottingham.

Towle, A., Bainbridge, L., Godolphin, W., Katz, A., Kline, K., Lown, B., Madularu, I., Solomon, P. \& Thistlethwaite, J. (2010) Active patient involvement in the education of health professionals. Medical Education, 44, 64-74.

Tritter, J. \& McCallum, A. (2006) The snakes and ladders of user involvement: moving beyond Arnstein. Health Policy, 76, 156-168.

Williamson, C. (2008) The patient movement as an emancipation movement. Health Expectations, 11: $102-112$. 
Wykurz, G. \& Kelly, D. (2002) Learning in practice - developing the role of patients as teachers: literature review. British Medical Journal, 325, 818-821. 